\title{
Preservation of grass juice and wet leaf protein concen- trate for animal feeds
}

\author{
MATTI NÄSI \\ Department of Animal Husbandry, University of Helsinki, SF-00710 Hel- \\ sinki 71
}

\begin{abstract}
Formic acid, mixtures of acids (AIV 1, AIV 2) and formalin-acid mixtures (Viher solution, Viher acid) were tested as preservatives of juice and wet leaf protein concentrate (LPC) obtained from grass, clover and pea. The main criteria used in judging the success of preservation were changes in the protein fraction, fermentation of sugars, and losses of dry matter and true protein during storage. Fermentation of sugars and moulding could be inhibited in plant juices by adding $0.5 \% \%$ preservative, but proteolysis continued and true protein was degraded in unheated juices. Ensiling losses of pea juice were considerable, $4.0-15.6 \%$ of DM, in all treatments. For wet leaf protein concentrate precipitated by steaming $\left(85^{\circ} \mathrm{C}\right)$, good preservation could be obtained with the additives used in silage making applied at a level of $1 \% \%$. In these treatments protein breakdown was minimal, because heating eliminated proteolytic enzymes and partly sterilized the LPC product.
\end{abstract}

\section{Introduction}

Juice from fresh green crops is very labile and its composition changes rapidly. Microbial growth and enzymic proteolysis deteriorate juice involving fermentation and a decrease in true protein content (CHEESEMAN 1977, STEWART and HOUSEMAN 1977, PIRIE 1978, NØRGAARD PEDERSEN et al. 1981). If juice cannot be fed to pigs in a short time after expression, preservation is needed to minimize protein breakdown and animo acid destruction. Storage and preservation are also required on account of seasonal and daily variation in plant juice production, and the need to standardize the product and save labour. Preservation is achieved by heating to inactivate proteolytic enzymes and adding chemicals to prevent microbial spoilage and inhibit undesirable chemical changes. Juice has also been preserved effectively by acidification to the low $\mathrm{pH}$ value of 3 together with the use of some bacteriostatic agent (CHEESEMAN 1977, BARBER et al. 1979, NØRGAARD PEDERSEN et al. 1981). STAHMANN (1978) proposed anaerobic fermentation as a suitable method for preserving grass juice and coagulated leaf protein.

Drying is the method most often used in preservation of leaf protein concentrate (FOXELL 1977). But comparison of air-dried and oven-dried 
samples with freeze-dried samples of leaf protein has shown that substantial damage can occur during drying, particularly when high temperatures or long drying times are involved (MORRISON 1977).

The purpose of the present investigation was to study whether acidification and formaldehyde treatment, the methods used in silage making, are a satisfactory means of preserving plant juice and wet leaf protein concentrate.

\section{Materials and methods}

The experiment consisted of ten preservation treatments of plant juice and eight of wet leaf protein concentrate (LPC). The procedure used for expression of juice and leaf protein coagulation is presented by NÄSI (1983 a). Grass, clover and pea juice in portions of $800-1000 \mathrm{~g}$ was stored in glass bottles for 90 days after adding small quantities, $0.25-1.0 \% \mathrm{\%}$ of the following: AIV 1 solution (inc. formic acid $27 \%$ and hydrochloric acid 22 $\%$ ), AIV 2 solution (formic acid $80 \%$ and phosphoric acid $2 \%$ ), Formic acid (conc. $86 \%$ ), Viher solution (formaldehyde $20 \%$ and acetic acid $24 \%$ ) and Viher acid (formaldehyde $10 \%$, formic acid $17 \%$ and sulphuric acid 22.5 $\%)$. Wet leaf protein concentrate was stored in $500-\mathrm{g}$ portions in plastic boxes for 120 days after application of additives at the rate of $0.5-3.0 \% \%$. The storage bottles and boxes were mixed thoroughly after addition of preservative and the $\mathrm{pH}$ was measured. The flasks were closed with parafilm and the boxes with tight covers, to prevent evaporation and in an attempt to maintain anaerobic conditions within the bottles and boxes. The storage temperature was $9-12^{\circ} \mathrm{C}$. Changes evident during storage, such as surface fungal contamination and fermentation, were also recorded. After storage the bottles and boxes were weighed and the losses calculated. Analyses were performed on freshly prepared material and on the stored samples. The $\mathrm{pH}$, dry matter, crude protein, true protein and water-soluble carbohydrates were determined immediately after storage by the standard methods. Ammonia nitrogen (McCULLOUGH 1967) lactic acid (BARKER and SUMMERSON 1941) and volatile fatty acids were determined later by gas-liquid chromatography (HUIDA 1973) on deep-frozen samples.

\section{Results and discussion}

Juice from green plants is a very labile product and deteriorates rapidly after extraction (Table 1). Without preservative, microbial activity causes detrimental changes, particularly in the carbohydrate fraction. This can be seen in the almost complete reduction of sugars and their fermentation to lactic acid and acetic acid, and in a fall of the $\mathrm{pH}$, which decreased from 5.3 to 4.2 during 7-day storage. Fermentation also caused dry matter (DM) losses; BAKON (1974) found that the soluble carbohydrate fraction could disappear within 24 hours. The protein content is decreased, especially the true protein fraction and ammonia is increased. The loss of true protein (TP) after 7-day 
Table 1. Changes during storage of clover juice (2) without preservative.

\begin{tabular}{lccccccccccc}
\hline $\begin{array}{l}\text { Time } \\
\text { of } \\
\text { storage }\end{array}$ & $\mathrm{pH}$ & $\begin{array}{c}\mathrm{DM} \\
\%\end{array}$ & $\begin{array}{c}\mathrm{CP} \\
\%\end{array}$ & $\begin{array}{c}\mathrm{TP} \\
\%\end{array}$ & $\begin{array}{c}\text { Sugars } \\
\%\end{array}$ & $\begin{array}{c}\mathrm{NH}_{3}-\mathrm{N} \\
\mathrm{mg} / \mathrm{l}\end{array}$ & $\begin{array}{c}\text { Lactic } \\
\text { acid } \\
\%\end{array}$ & $\begin{array}{c}\text { Acetic } \\
\text { acid } \\
\%\end{array}$ & $\begin{array}{c}\text { Loss } \\
\text { of } \mathrm{DM} \\
\%\end{array}$ & $\begin{array}{c}\text { Loss } \\
\text { of TP } \\
\%\end{array}$ & $\begin{array}{c}\mathrm{TP}-\mathrm{CP} \\
\text { ratio }\end{array}$ \\
\hline Fresh & & & & & & & & & & & \\
juice & 5.33 & 7.49 & 1.80 & 0.84 & 1.49 & 62 & 0.24 & 0.10 & - & & 46.6 \\
$7 \mathrm{~d}$ & 4.21 & 7.32 & 1.59 & 0.71 & 0.06 & 81 & 1.96 & 0.29 & 2.3 & 13.4 & 44.7 \\
$14 \mathrm{~d}$ & 4.22 & 7.04 & 1.53 & 0.65 & 0.05 & 79 & 2.10 & 0.37 & 6.0 & 17.9 & 42.5 \\
$28 \mathrm{~d}$ & 4.25 & 7.06 & 1.46 & 0.62 & 0.04 & 85 & 2.32 & 0.41 & 5.8 & 21.4 & 42.5 \\
\hline
\end{tabular}

Table 2. Changes during storage of grass juice (grass 3 and $4,1980, n=2$ ) preserved with different additives.

\begin{tabular}{|c|c|c|c|c|c|c|c|c|c|c|c|c|}
\hline \multirow{2}{*}{ No } & \multicolumn{2}{|c|}{$\mathrm{pH}$} & \multirow{2}{*}{$\begin{array}{c}\text { DM } \\
\%\end{array}$} & \multirow{2}{*}{$\begin{array}{c}\text { CP } \\
\%\end{array}$} & \multirow{2}{*}{$\begin{array}{l}\text { TP } \\
\%\end{array}$} & \multirow{2}{*}{$\begin{array}{c}\text { Sugars } \\
\%\end{array}$} & \multirow{2}{*}{$\begin{array}{c}\mathrm{NH}_{3}-\mathrm{N} \\
\mathrm{mg} / \mathrm{l}\end{array}$} & \multirow{2}{*}{$\begin{array}{c}\text { Lactic } \\
\text { acid } \\
\%\end{array}$} & \multirow{2}{*}{$\begin{array}{c}\text { Acetic } \\
\text { acid } \\
\%\end{array}$} & \multirow{2}{*}{$\begin{array}{c}\text { Loss } \\
\text { of DM } \\
\%\end{array}$} & \multirow{2}{*}{$\begin{array}{l}\text { Loss } \\
\text { of TP }\end{array}$} & \multirow{2}{*}{$\begin{array}{c}\text { TP-CP } \\
\text { ratio }\end{array}$} \\
\hline & $1 \mathrm{~d}$ & $90 \mathrm{~d}$ & & & & & & & & & & \\
\hline 1 & 5.80 & - & 6.08 & 1.27 & 0.40 & 2.44 & 24 & 0.01 & - & - & - & 31.5 \\
\hline 2 & 5.80 & 4.72 & 4.70 & 1.29 & 0.42 & 0.19 & 171 & 0.94 & 0.12 & 22.1 & 10.5 & 32.6 \\
\hline 3 & 4.66 & 4.43 & 5.19 & 1.33 & 0.42 & 0.18 & 58 & 0.62 & 0.17 & 14.3 & 10.2 & 31.6 \\
\hline 4 & 4.19 & 4.33 & 6.01 & 1.32 & 0.43 & 2.37 & 37 & 0.01 & 0.16 & 0.7 & 6.9 & 32.6 \\
\hline 5 & 4.09 & 4.13 & 6.05 & 1.32 & 0.41 & 2.40 & 33 & 0.01 & 0.02 & 0.0 & 11.2 & 31.1 \\
\hline 6 & 4.44 & 4.48 & 5.87 & 1.31 & 0.41 & 2.24 & 38 & 0.02 & 0.03 & 3.1 & 13.8 & 31.3 \\
\hline 7 & 4.10 & 4.14 & 5.99 & 1.30 & 0.44 & 2.33 & 36 & 0.01 & 0.02 & 1.2 & 5.5 & 33.8 \\
\hline 8 & 5.51 & 5.39 & 5.84 & 1.38 & 0.40 & 2.35 & 51 & 0.01 & 0.08 & 3.6 & 12.4 & 29.0 \\
\hline 9 & 5.20 & 5.08 & 5.96 & 1.38 & 0.46 & 2.42 & 69 & 0.01 & 0.14 & 1.5 & 0.2 & 33.0 \\
\hline 10 & 4.45 & 4.68 & 5.66 & 1.35 & 0.46 & 2.05 & 38 & 0.02 & 0.02 & 7.4 & 1.9 & 34.0 \\
\hline
\end{tabular}

Additives: 1) Fresh juice, 2) No preservative, 3) $0.25 \% \mathrm{~V} / \mathrm{w}$ AIV 1 solution, 4) $0.5 \% \mathrm{v} / \mathrm{w}$ AIV 1 solution, 5) $0.5 \% \mathrm{v} / \mathrm{w}$ AIV 2 solution, 6) $0.25 \% \mathrm{v} / \mathrm{w}$ Formic acid, 7) $0.5 \% \mathrm{v} / \mathrm{w}$ Formic acid, 8 ) $0.25 \mathrm{v} / \mathrm{w}$ Viher solution, 9) $0.5 \% \mathrm{v} / \mathrm{w}$ Viher solution, 10) $0.5 \% \mathrm{v} / \mathrm{w}$ Viher acid.

storage was $13.4 \%$ and after 28 days $21.4 \%$. Non-protein nitrogen (NPN) was reported to increase during storage of unheated lucerne juice, from $20 \%$ in freshly prepared juice to $30 \%$ in $4 \mathrm{~h}$ and $40 \%$ in $24 \mathrm{~h}$ (CONNELL and FOXELL 1976). In the present study the initial TP:CP ratio of fresh clover juice was $46.6 \%$ and in juice stored for 28 days the value had decreased by $4.1 \%$ units. In all the experiments the time from processing the juice to the preservative treatment was 3-5 h. Protein breakdown is caused by proteolytic activity in the juice and by microbial enzymes. Heat treatment to inactivate endogenous enzymes halts the deterioration initially, but further preservative treatment is required to control microbial spoilage (CHEESEMAN 1977, BARBER et al. 1979, NØRGAARD PEDERSEN et al. 1981).

The batches of grass, clover and pea juice were treated with different ensiling additives at various concentrations. The changes in chemical composition during storage are given in Tables $2-4$, in which the results of replicate treatments have been pooled. Preliminary comparisons of different 
additives and different application levels had been made in the preceding year. The results of those trials were used as a basis for the present quantitative and qualitative evaluation of preservation, in which attention was concentrated on the changes in the protein fraction, fermentation of sugars and losses of dry matter and true protein. After 90 -day storage the chemical composition was analysed in all treatments and the values were compared with each other and with those of fresh juice.

In grass juice the initial TP content was low, only $0.4 \%$, and the TP:CP ratio was as low as $32 \%$ (Table 2). In the unpreserved sample after storage, the $\mathrm{pH}$ value was 4.7 and the sugars had mostly been fermented to lactic acid and partly to acetic acid; the TP losses were $10.5 \%$ and ammonia had increased to $8.6 \%$ of total nitrogen. Additive application levels of $0.25-0.5$ $\%$ were adequate to prevent microbial fermentation, except in the case of 0.25 $\%$ AIV 1 solution. The increase of $\mathrm{NH}_{3}-\mathrm{N}$ was also halted by the additives. The overall high proportion of NPN in total CP was caused by the endogenous proteolysis occurring in unheated juice. TP losses were thus quite marked in the samples containing additives, 5-14\%, in spite of the fact that the microbial fermentation of sugars was prevented.

In the preservation of clover juice, additive levels of $0.25 \%$ were not sufficient to prevent sugar fermentation, as can be seen from the increase in the concentrations of lactic and acetic acid (Table 3 ). The $\mathrm{pH}$ values in those treatments also rose during storage, indicating secondary fermentation. Additive levels of $0.5 \%$ were adequate.

Pea juice had high TP losses in all preservation treatments (Table 4). $\mathrm{NH}_{3}$ $-\mathrm{N}$ increased greatly during storage. Heterofermentation appeared to occur, because the acetic acid concentrations were much higher than in the grass or

Table 3. Changes during storage of clover juice (clover $3-6,1980, n=4$ ) preserved with different additives.

\begin{tabular}{|c|c|c|c|c|c|c|c|c|c|c|c|c|}
\hline \multirow{2}{*}{ No } & \multicolumn{2}{|c|}{$\mathrm{pH}$} & \multirow{2}{*}{$\begin{array}{c}\text { DM } \\
\%\end{array}$} & \multirow{2}{*}{$\begin{array}{l}\text { CP } \\
\%\end{array}$} & \multirow{2}{*}{$\begin{array}{l}\text { TP } \\
\%\end{array}$} & \multirow{2}{*}{$\begin{array}{c}\text { Sugars } \\
\%\end{array}$} & \multirow{2}{*}{$\begin{array}{c}\mathrm{NH}_{3}-\mathrm{N} \\
\mathrm{mg} / \mathrm{l}\end{array}$} & \multirow{2}{*}{$\begin{array}{c}\text { Lactic } \\
\text { acid } \\
\%\end{array}$} & \multirow{2}{*}{$\begin{array}{c}\text { Acetic } \\
\text { acid } \\
\%\end{array}$} & \multirow{2}{*}{$\begin{array}{c}\text { Loss } \\
\text { of DM } \\
\%\end{array}$} & \multirow{2}{*}{$\begin{array}{l}\text { Loss } \\
\text { of TP }\end{array}$} & \multirow{2}{*}{$\begin{array}{l}\text { TP-CP } \\
\text { ratio }\end{array}$} \\
\hline & $1 \mathrm{~d}$ & $90 \mathrm{~d}$ & & & & & & & & & & \\
\hline 1 & 5.77 & - & 7.35 & 1.53 & 0.91 & 2.16 & 14 & 0.01 & - & - & - & 59.5 \\
\hline 2 & 5.77 & 4.61 & 6.49 & 1.59 & 0.79 & 0.44 & 161 & 1.30 & 0.22 & 11.6 & 19.7 & 49.7 \\
\hline 3 & 5.16 & 4.27 & 6.84 & 1.64 & 0.80 & 0.72 & 56 & 1.30 & 0.28 & 7.0 & 11.0 & 48.8 \\
\hline 4 & 4.54 & 4.28 & 6.96 & 1.60 & 0.94 & 1.47 & 31 & 0.20 & 0.06 & 5.2 & 6.9 & 58.8 \\
\hline 5 & 4.06 & 4.08 & 7.54 & 1.61 & 0.88 & 2.22 & 15 & 0.01 & 0.02 & 0.0 & 8.0 & 54.7 \\
\hline 6 & 4.95 & 4.42 & 6.94 & 1.60 & 0.83 & 1.29 & 37 & 0.59 & 0.12 & 5.7 & 9.1 & 51.9 \\
\hline 7 & 4.37 & 4.06 & 7.40 & 1.60 & 0.86 & 2.10 & 14 & 0.01 & 0.02 & 0.0 & 8.4 & 53.8 \\
\hline 8 & 5.48 & 4.94 & 6.51 & 1.63 & 0.82 & 0.52 & 35 & 0.35 & 0.12 & 11.6 & 8.9 & 50.3 \\
\hline 9 & 5.16 & 5.11 & 7.11 & 1.65 & 0.93 & 1.74 & 16 & 0.01 & 0.12 & 3.2 & 2.2 & 56.4 \\
\hline 10 & 4.89 & 4.40 & 6.84 & 1.70 & 0.91 & 1.05 & 28 & 0.20 & 0.08 & 7.0 & 5.0 & 53.5 \\
\hline
\end{tabular}

Additives: 1) Fresh juice, 2) No preservative, 3) $0.25 \% \mathrm{v} / \mathrm{w}$ AIV 1 solution, 4) $0.5 \% \mathrm{v} / \mathrm{w}$ AIV 1 solution, 5) $0.5 \%$ v/w AIV 2 solution, 6) $0.25 \%$ v/w Formic acid, 7) $0.5 \%$ v/w Formic acid, 8) $0.25 \mathrm{v} / \mathrm{w}$ Viher solution, 9) $0.5 \% \mathrm{v} / \mathrm{w}$ Viher solution, 10) $0.5 \% \mathrm{v} / \mathrm{w}$ Viher acid. 
Table 4. Changes during storage of pea juice preserved with different additives.

\begin{tabular}{|c|c|c|c|c|c|c|c|c|c|c|c|c|}
\hline \multirow{2}{*}{ No } & \multicolumn{2}{|c|}{$\mathrm{pH}$} & \multirow{2}{*}{$\begin{array}{c}\text { DM } \\
\%\end{array}$} & \multirow{2}{*}{$\begin{array}{l}\text { CP } \\
\%\end{array}$} & \multirow{2}{*}{$\begin{array}{l}\text { TP } \\
\%\end{array}$} & \multirow{2}{*}{$\begin{array}{c}\text { Sugars } \\
\%\end{array}$} & \multirow{2}{*}{$\begin{array}{c}\mathrm{NH}_{3}-\mathrm{N} \\
\mathrm{mg} / \mathrm{l}\end{array}$} & \multirow{2}{*}{$\begin{array}{c}\text { Lactic } \\
\text { acid } \\
\%\end{array}$} & \multirow{2}{*}{$\begin{array}{c}\text { Acetic } \\
\text { acid } \\
\%\end{array}$} & \multirow{2}{*}{$\begin{array}{c}\text { Loss } \\
\text { of DM } \\
\%\end{array}$} & \multirow{2}{*}{$\begin{array}{l}\text { Loss } \\
\text { of TP }\end{array}$} & \multirow{2}{*}{$\begin{array}{l}\text { TP-CP } \\
\text { ratio }\end{array}$} \\
\hline & $1 \mathrm{~d}$ & $90 \mathrm{~d}$ & & & & & & & & & & \\
\hline 1 & 5.60 & & 4.56 & 1.69 & 0.79 & 1.29 & 55 & 0.01 & - & - & - & 46.7 \\
\hline 2 & 5.60 & 5.34 & 3.48 & 1.67 & 0.36 & 0.01 & 372 & 0.45 & 0.47 & 23.5 & 55.1 & 21.6 \\
\hline 3 & 4.30 & 4.45 & 3.85 & 1.69 & 0.32 & 0.02 & 381 & 1.07 & 0.33 & 15.6 & 60.1 & 18.9 \\
\hline 4 & 3.86 & 3.69 & 4.31 & 1.63 & 0.37 & 0.05 & 189 & 1.31 & 0.18 & 5.5 & 53.5 & 22.7 \\
\hline 5 & 4.20 & 4.02 & 4.17 & 1.65 & 0.37 & 0.09 & 336 & 1.11 & 0.16 & 8.6 & 50.2 & 22.4 \\
\hline 6 & 3.78 & 3.79 & 4.36 & 1.61 & 0.36 & 1.21 & 89 & 0.01 & 0.04 & 4.4 & 54.2 & 22.4 \\
\hline 7 & 3.80 & 4.09 & 4.19 & 1.65 & 0.39 & 0.68 & 151 & 0.48 & 0.15 & 8.1 & 50.6 & 23.6 \\
\hline 8 & 5.12 & 5.38 & 4.21 & 1.64 & 0.57 & 1.21 & 265 & 0.02 & 0.13 & 7.7 & 27.8 & 34.8 \\
\hline 9 & 4.94 & 4.95 & 4.38 & 1.72 & 0.68 & 1.33 & 149 & 0.04 & 0.16 & 4.0 & 14.2 & 39.5 \\
\hline 10 & 4.60 & 4.05 & 4.30 & 1.72 & 0.38 & 0.02 & 256 & 1.43 & 0.20 & 5.7 & 52.5 & 22.1 \\
\hline 11 & 4.20 & 3.75 & 4.29 & 1.76 & 0.47 & 0.14 & 124 & 1.26 & 0.10 & 5.9 & 40.5 & 26.7 \\
\hline
\end{tabular}

Additives: 1) Fresh juice, 2) No preservative, 3) $0.3 \% \mathrm{v} / \mathrm{w}$ AIV 1 solution, 4) $0.5 \% \mathrm{v} / \mathrm{w}$ AIV 1 solution, 5) $0.3 \%$ v $/ w$ AIV 2 solution, 6) $0.5 \%$ v/w AIV 2 solution, 7) $0.5 \%$ v/w Formic acid, 8) $0.3 \% \mathrm{v} / \mathrm{w}$ Viher solution, 9) $0.5 \% \mathrm{v} / \mathrm{w}$ Viher solution, 10) $0.3 \% \mathrm{v} / \mathrm{w}$ Viher acid, 11) $0.5 \% \mathrm{v} / \mathrm{w}$ Viher acid.

clover treatments. Traces of propionic and butyric acid were also found. True protein was strongly degraded; the TP:CP ratios were rather low, 19-39\%.

Considerable differences in preservation results existed between the juices derived from different plants and also between the different additive applications levels. The protein content varied between the juices and leguminous plant juice evidently has a greater buffering capacity than grass juice; its water-soluble carbohydrate content is also low compared with that of grass juice (McDONALD 1981).

The results indicated that degradation of true protein and amino acids in juice can be restrained by lowering the $\mathrm{pH}$. However, to obtain complete preservation the $\mathrm{pH}$ must be lowered under 3,0 (CHEESEMAN 1977, STEWART and HOUSEMAN 1977, BARBER et al. 1979). Good preservation was also obtained by adding formalin or by heating to $80^{\circ} \mathrm{C}$ (NØRGAARD PEDERSEN et al. 1981). The degradation of true protein was generally more pronounced than the degradation of amino acids, which means that an important part of the degradation of true protein was proteolysis, because the increase in the $\mathrm{NH}_{3}-\mathrm{N}$ content of the juice was not as great as the decrease in TP.

Development of lactic acid bacteria occurred even in grass juice acidified to low $\mathrm{pH}$ values with $\mathrm{HCl}$, but addition of $1 \% \mathrm{Na}_{2} \mathrm{~S}_{2} \mathrm{O}_{5}$ prevented growth of bacteria and yeasts (STEWART and HOUSEMAN 1977). A bacteriostatic effect is exerted by fatty acids, formic, acetic and propionic acids (PRIGGE and HEIER 1982), and these give better preservation than mineral acids, whose effect in only due to the drop in $\mathrm{pH}$. In the present investigation formic acid was effective in preventing fermentation and protein degradation was comparatively moderate. Additives containing formalin also gave satisfactory 
preservation and comparatively slight breakdown of TP. When formaldehyde was used as preservative, good results were obtained by PATTERSON and WALKER (1979) and NØRGAARD PEDERSEN et al. (1981), but not so good by CHEESEMAN (1977).

When plant juice is used as protein source in pig feeds, it is important to give either fresh juice or juice preserved properly to prevent protein degradation and amino acid destruction; otherwise the performance of pigs deteriorates (BARBER et al. 1979).

According to the results of the present investigation plant juices can be preserved with the additives used in making silage, and, used at adequate levels $(0.5 \%)$, these will prevent microbial fermentation. The juices should be heated shortly after extraction and before treatment with preservative, to prevent enzymic proteolysis.

Clover leaf protein concentrate (LPC) was preserved with various additives applied at levels of $0.5-3,0 \%$ (Table 5) to determine what amount is sufficient for ensiling. The criteria used in evaluating preservation were losses of dry matter and water-soluble sugars, indicative of microbial fermentation, and the decline of TP and the TP:CP ratio, indicative of protein breakdown. The storage time in all the treatments was four months. LPC was precipitated

Table 5. Changes during storage of leaf protein concentrate of clover (1) preserved with various additives.

\begin{tabular}{|c|c|c|c|c|c|c|c|c|c|}
\hline \multirow{2}{*}{ No } & \multicolumn{2}{|c|}{$\mathrm{pH}$} & \multirow{2}{*}{$\begin{array}{c}\text { DM } \\
\%\end{array}$} & \multirow{2}{*}{$\begin{array}{l}\text { CP } \\
\%\end{array}$} & \multirow{2}{*}{$\begin{array}{l}\text { TP } \\
\%\end{array}$} & \multirow{2}{*}{$\begin{array}{c}\text { Sugars } \\
\%\end{array}$} & \multirow{2}{*}{$\begin{array}{c}\text { Loss of } \\
\text { DM } \\
\%\end{array}$} & \multirow{2}{*}{$\begin{array}{c}\text { Loss of } \\
\text { TP } \\
\%\end{array}$} & \multirow{2}{*}{$\begin{array}{c}\text { TP-CP } \\
\text { ratio }\end{array}$} \\
\hline & $1 \mathrm{~d}$ & $120 \mathrm{~d}$ & & & & & & & \\
\hline 1 & 5.64 & - & 12.40 & 4.88 & 4.41 & 1.50 & & - & 90.4 \\
\hline 2 & 5.64 & - & 91.7 & 37.7 & 29.7 & 13.9 & - & - & 78.8 \\
\hline 3 & 5.71 & 6.61 & 9.94 & 5.62 & 4.38 & 0.04 & 29.0 & 2.7 & 77.9 \\
\hline 4 & 3.98 & 4.84 & 10.57 & 5.15 & 4.31 & 0.10 & 18.4 & 3.7 & 83.7 \\
\hline 5 & 3.22 & 5.54 & 10.65 & 5.04 & 4.30 & 0.81 & 17.5 & 3.5 & 85.3 \\
\hline 6 & 2.52 & 2.90 & 12.18 & 4.96 & 4.18 & 1.48 & 3.0 & 3.7 & 84.3 \\
\hline 7 & 1.70 & 2.34 & 12.35 & 4.89 & 4.09 & 1.55 & 0.7 & 4.8 & 83.6 \\
\hline 8 & 3.70 & 4.08 & 11.97 & 5.00 & 4.23 & 1.86 & 6.5 & 4.8 & 84.6 \\
\hline 9 & 3.29 & 3.70 & 11.97 & 4.94 & 4.20 & 1.58 & 5.7 & 4.2 & 85.0 \\
\hline 10 & 3.02 & 3.22 & 12.04 & 4.88 & 4.08 & 1.59 & 3.9 & 5.9 & 83.6 \\
\hline 11 & 2.99 & 3.00 & 12.01 & 4.84 & 4.07 & 1.51 & 3.3 & 5.2 & 84.0 \\
\hline 12 & 3.29 & 3.60 & 12.76 & 5.39 & 4.45 & 1.55 & 0.0 & 0.0 & 82.6 \\
\hline 13 & 2.89 & 3.00 & 12.87 & 5.27 & 5.00 & 1.40 & 0.0 & 0.0 & 94.9 \\
\hline 14 & 4.73 & 6.00 & 10.96 & 5.46 & 4.97 & 0.37 & 15.0 & 0.0 & 91.0 \\
\hline 15 & 4.21 & 4.48 & 13.25 & 5.55 & 4.80 & 1.50 & 0.0 & 0.0 & 86.5 \\
\hline 16 & 3.90 & 4.22 & 12.64 & 5.63 & 4.68 & 1.44 & 1.2 & 0.0 & 83.1 \\
\hline 17 & 2.90 & 2.90 & 13.34 & 5.67 & 4.59 & 1.46 & 0.0 & 0.0 & 80.9 \\
\hline
\end{tabular}

Additives: 1) Fresh LPC, 2) Dried LPC, 3) No preservative, 4) $0.5 \%$ v/w AIV 1 solution, 5) $1.0 \% \mathrm{v} / \mathrm{w}$ AIV 1 solution, 6) $2.0 \% \mathrm{v} / \mathrm{w}$ AIV 1 solution, 7) $3.0 \% \mathrm{v} / \mathrm{w}$ AIV 1 solution, 8 ) $0.5 \% \mathrm{v} / \mathrm{w}$ AIV 2 solution, 9) $1.0 \% \mathrm{v} / \mathrm{w}$ AIV solution, 10) $2.0 \% \mathrm{v} / \mathrm{w}$ AIV 2 solution, 11) $3.0 \% \mathrm{v} / \mathrm{wAIV} 2$ solution, 12) $1.0 \% \mathrm{v} / \mathrm{w}$ Formic acid, 13) $3.0 \% \mathrm{v} / \mathrm{w}$ Formic acid, 14) $1.0 \% \mathrm{v} / \mathrm{w}$ Viher solution, 15) $3.0 \% \mathrm{v} / \mathrm{w}$ Viher solution, 16) $1.0 \% \mathrm{v} / \mathrm{w}$ Viher acid and 17) $3.0 \% \mathrm{v} / \mathrm{w}$ Viher acid. 
by heating the juice with steam injection to $85^{\circ} \mathrm{C}$, which eliminated the proteolytic enzymes and also partly sterilized the material. The effectiveness of preservation differed between additives and application levels. The $1 \%$ level was otherwise adequate, but in the case of AIV 1 and Viher solution was insufficient to prevent carbohydrate fermentation. In those samples $\mathrm{pH}$ increased from its initial value and the sugar content decreased, indicating secondary fermentation.

Table 6 presents the chemical changes taking place during storage of pea LPC with various additives used at two levels, 0.6 and $1.0 \%$. With the lower level, sugar fermentation occurred in all the treatments, although the $\mathrm{pH}$ was under 4.0, and this caused considerable losses of DM, 9-11.5\%. The losses of TP were also higher than in the grass or clover LPC treatments. These losses were also relatively high during storage of pea juice compared with the losses in grass and clover juices.

Grass LPC was preserved with various additives at the $1.0 \%$ level. In Table 6 the results of two series have been pooled. The DM losses during storage were $3.7-4.5 \%$ and the TP losses $5.0-7.9 \%$. Fermentation of sugars was slight. A minor increase in the $\mathrm{pH}$ values indicated liberation of ammonia in proteolysis. The initial $\mathrm{pH}$ value was rather low, 5.0, indicating that slight fermentation had occurred before preservation. The differences between additives were small.

Table 8 presents the pooled results of four series of preservation treatments of clover LPC precipitated by heating or by combined heating and acidification $(0.5 \% \mathrm{HCl})$. There were some differences in the chemical

Table 6. Changes during storage of leaf protein concentratesof pea preserved with different additives.

\begin{tabular}{|c|c|c|c|c|c|c|c|c|c|}
\hline \multirow{2}{*}{ No } & \multicolumn{2}{|c|}{$\mathrm{pH}$} & \multirow{2}{*}{$\begin{array}{c}\text { DM } \\
\%\end{array}$} & \multirow{2}{*}{$\begin{array}{l}\text { TP } \\
\%\end{array}$} & \multirow{2}{*}{$\begin{array}{l}\mathrm{CP} \\
\%\end{array}$} & \multirow{2}{*}{$\begin{array}{c}\text { Sugars } \\
\%\end{array}$} & \multirow{2}{*}{$\begin{array}{c}\text { Loss of } \\
\text { DM } \\
\%\end{array}$} & \multirow{2}{*}{$\begin{array}{c}\text { Loss of } \\
\text { TP } \\
\%\end{array}$} & \multirow{2}{*}{$\begin{array}{c}\text { TP-CP } \\
\text { ratio }\end{array}$} \\
\hline & $1 \mathrm{~d}$ & $120 \mathrm{~d}$ & & & & & & & \\
\hline 1 & 5.77 & - & 11.06 & 5.83 & 5.01 & 1.01 & & - & 85.9 \\
\hline 2 & 5.77 & - & 90.5 & 59.2 & 49.9 & 1.0 & - & - & 84.3 \\
\hline 3 & 5.90 & 4.62 & 11.13 & 6.42 & 5.42 & 0.04 & 14.5 & 10.2 & 84.4 \\
\hline 4 & 3.90 & 3.90 & 11.59 & 6.63 & 5.46 & 0.22 & 11.2 & 8.5 & 82.4 \\
\hline 5 & 3.20 & 3.55 & 11.31 & 6.51 & 5.27 & 0.94 & 11.3 & 9.0 & 80.9 \\
\hline 6 & 3.90 & 3.88 & 11.21 & 6.34 & 5.27 & 0.95 & 10.0 & 7.5 & 83.1 \\
\hline 7 & 3.40 & 3.55 & 11.02 & 6.43 & 5.06 & 1.05 & 10.9 & 9.4 & 78.7 \\
\hline 8 & 3.50 & 3.87 & 11.33 & 6.41 & 5.36 & 0.76 & 11.4 & 8.5 & 83.6 \\
\hline 9 & 3.44 & 3.51 & 11.12 & 6.28 & 5.14 & 0.92 & 11.0 & 9.1 & 81.8 \\
\hline 10 & 5.10 & 4.38 & 11.73 & 6.86 & 5.79 & 0.54 & 11.5 & 8.4 & 84.4 \\
\hline 11 & 4.76 & 4.92 & 11.14 & 6.34 & 5.44 & 1.04 & 10.1 & 5.9 & 85.8 \\
\hline 12 & 3.84 & 3.92 & 11.88 & 6.64 & 5.52 & 0.31 & 9.9 & 8.4 & 83.1 \\
\hline 13 & 3.54 & 3.90 & 11.27 & 6.39 & 5.23 & 0.86 & 8.7 & 6.9 & 81.8 \\
\hline
\end{tabular}

Additives: 1) Fresh LPC, 2) Dried LPC, 3) No preservative, 4) $0.6 \% \mathrm{v} / \mathrm{w}$ AIV 1 solution, 5) $1.0 \% \mathrm{c} / \mathrm{w}$ AIV 1 solution, 6) $0.6 \% \mathrm{~V} / \mathrm{wAIV} 2$ solution, 7) $1.0 \% \mathrm{~V} / \mathrm{w}$ AIV 2 solution, 8 ) $0.6 \% \mathrm{~V} / \mathrm{w}$ Formic acid, 9) $1.0 \% \mathrm{v} / \mathrm{w}$ Formic acid, 10) $0.6 \% \mathrm{v} / \mathrm{w}$ Viher solution, 11) $1.0 \% \mathrm{v} / \mathrm{w}$ Viher solution, 12) $0.6 \% \mathrm{v} / \mathrm{w}$ Viher acid and 13$) 1.0 \% \mathrm{v} / \mathrm{w}$ Viher acid. 
Table 7. Changes during storage of leaf protein concentrates of pasture grass (grass 3 and $4,1980, n=2$ ) preserved with different additives.

\begin{tabular}{|c|c|c|c|c|c|c|c|c|c|}
\hline \multirow{2}{*}{ No } & \multicolumn{2}{|c|}{$\mathrm{pH}$} & \multirow{2}{*}{$\begin{array}{c}\text { DM } \\
\%\end{array}$} & \multirow{2}{*}{$\begin{array}{l}\mathrm{CP} \\
\%\end{array}$} & \multirow{2}{*}{$\begin{array}{l}\text { TP } \\
\%\end{array}$} & \multirow{2}{*}{$\begin{array}{c}\text { Sugars } \\
\%\end{array}$} & \multirow{2}{*}{$\begin{array}{c}\text { Loss of } \\
\text { DM } \\
\%\end{array}$} & \multirow{2}{*}{$\begin{array}{c}\text { Loss of } \\
\text { TP } \\
\%\end{array}$} & \multirow{2}{*}{$\begin{array}{c}\text { TP-CP } \\
\text { ratio }\end{array}$} \\
\hline & $1 \mathrm{~d}$ & $120 \mathrm{~d}$ & & & & & & & \\
\hline 1 & 4.98 & - & 13.59 & 5.72 & 4.89 & 1.67 & - & - & 85.5 \\
\hline 2 & - & - & 91.7 & 41.0 & 36.5 & 6.9 & - & - & 89.0 \\
\hline 3 & 4.98 & 4.58 & 13.40 & 5.50 & 4.68 & 0.37 & 6.5 & 5.8 & 85.1 \\
\hline 4 & 4.10 & 4.40 & 13.57 & 5.39 & 4.63 & 1.62 & 4.5 & 6.7 & 85.9 \\
\hline 5 & 4.06 & 4.14 & 13.60 & 5.42 & 4.58 & 1.56 & 4.8 & 7.9 & 84.5 \\
\hline 6 & 3.89 & 4.09 & 13.54 & 5.44 & 4.53 & 1.62 & 4.7 & 7.6 & 83.3 \\
\hline 7 & 4.75 & 5.10 & 13.59 & 5.53 & 4.70 & 1.63 & 3.7 & 5.0 & 85.0 \\
\hline 8 & 4.21 & 4.63 & 13.60 & 5.47 & 4.68 & 1.79 & 3.7 & 5.3 & 85.6 \\
\hline
\end{tabular}

Additives: 1) Fresh LPC, 2) Dried LPC, 3) No preservative, 4) $1.0 \% \mathrm{v} / \mathrm{w}$ AIV 1 solution, 5$) 1.0 \% \mathrm{v} / \mathrm{w}$ AIV 2 solution, 6) $1.0 \% \mathrm{v} / \mathrm{w}$ Formic acid, 7) $1.0 \% \mathrm{v} / \mathrm{w}$ Viher solution and 8 ) $1.0 \% \mathrm{v} / \mathrm{w}$ Viher acid.

Table 8. Changes during storage of clover leaf protein concentrates (clover $3-6,1980, n=4)$ preserved with different additives.

\begin{tabular}{|c|c|c|c|c|c|c|c|c|c|}
\hline \multirow{2}{*}{ No } & \multicolumn{2}{|c|}{$\mathrm{pH}$} & \multirow{2}{*}{$\begin{array}{c}\text { DM } \\
\%\end{array}$} & \multirow{2}{*}{$\begin{array}{l}\mathrm{CP} \\
\%\end{array}$} & \multirow{2}{*}{$\begin{array}{l}\text { TP } \\
\%\end{array}$} & \multirow{2}{*}{$\begin{array}{c}\text { Sugars } \\
\%\end{array}$} & \multirow{2}{*}{$\begin{array}{c}\text { Loss of } \\
\text { DM } \\
\%\end{array}$} & \multirow{2}{*}{$\begin{array}{c}\text { Loss of } \\
\text { TP } \\
\%\end{array}$} & \multirow{2}{*}{$\begin{array}{c}\text { TP-CP } \\
\text { ratio }\end{array}$} \\
\hline & $1 \mathrm{~d}$ & $120 \mathrm{~d}$ & & & & & & & \\
\hline
\end{tabular}

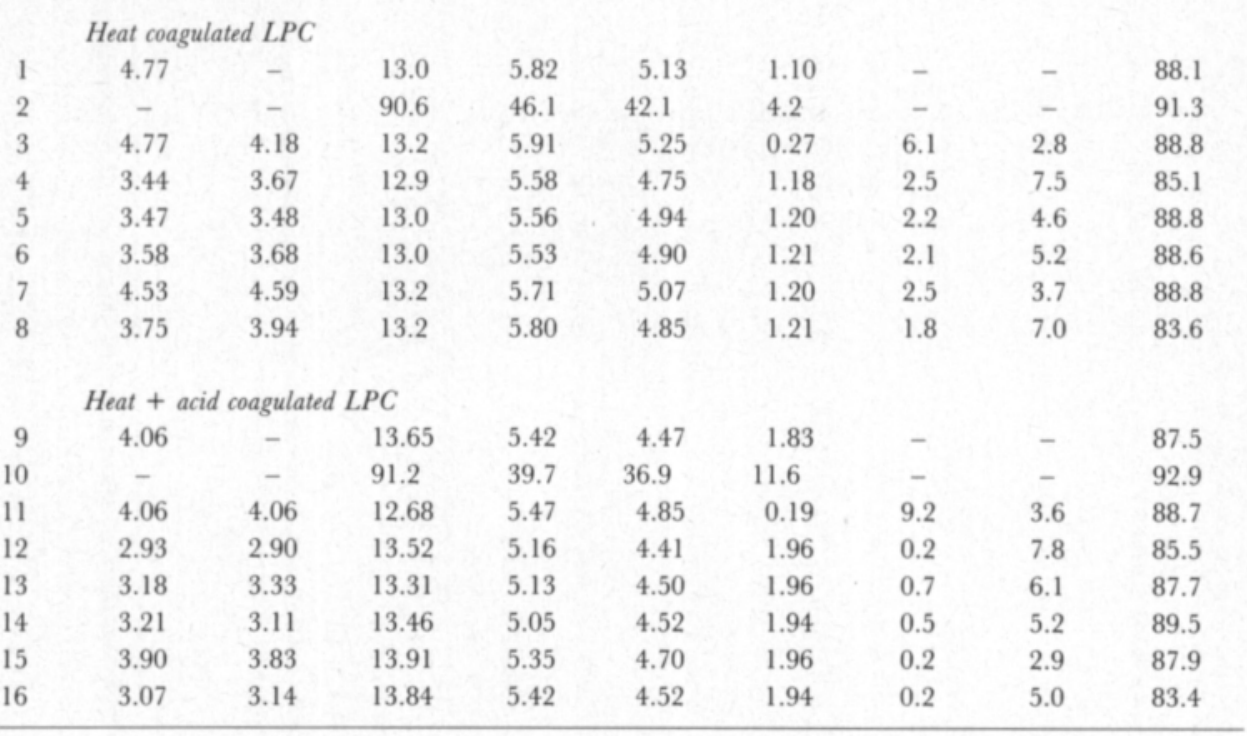

Additives: 1) Fresh LPC, 2) Dried LPC, 3) No preservative, 4) $1 \% \mathrm{v} / \mathrm{w}$ AIV 1 solution, 5) $1.0 \% \mathrm{v} / \mathrm{w}$ AIV 2 solution, 6) $1.0 \% \mathrm{v} / \mathrm{w}$ Formic acid, 7) $1 \% \mathrm{v} / \mathrm{w}$ Viher solution, 8) $1 \% \mathrm{v} / \mathrm{w}$ Viher acid, 9) Fresh LPC $0.5 \%$ v/w HCl, 10) Dried LPC $0.5 \%$ v/w HCl, 11) $0.5 \%$ v/w $\mathrm{HCl} 12) 0.5 \%$ \% $/ w \mathrm{HCl}+1$ $\% \mathrm{v} / \mathrm{w}$ AIV 1 solution, 13) $0.5 \% \mathrm{v} / \mathrm{w} \mathrm{HCl}+1 \% \mathrm{v} / \mathrm{w}$ AIV 2 solution, 14) $0.5 \% \mathrm{v} / \mathrm{w} \mathrm{HCl}+1 \%$ $\mathrm{v} / \mathrm{w}$ Formic acid, 5) $0.5 \% \mathrm{v} / \mathrm{w} \mathrm{HCl}+1 \% \mathrm{v} / \mathrm{w}$ Viher solution and 16$) 0.5 \% \mathrm{v} / \mathrm{w} \mathrm{HCl}+1 \%$ v/wViher acid. 
composition of the LPC obtained by the two techniques; the acidified LPC had a lower $\mathrm{pH}$, while the LPC precipitated by heating alone had higher $\mathrm{CP}$ and TP contents, but a lower sugar content (NÄSI $1983 \mathrm{a}, \mathrm{b}$ ). All additives gave satisfactory preservation; fermentation was minimal and protein degradation was low. $\mathrm{HCl}$ at the $0.5 \%$, level of application gave almost the same preservation results as those for untreated heated LPC.

Wet LPC from grass, clover and pea was effectively preserved by the additives normally used for grass silage applied at the $1 \% \mathrm{v} / \mathrm{w}$ level. Earlier results have also indicated that organic acids, formic, acetic and propionic acid give good preservation of various types of LPC at levels of $0.8-1.4 \%$, formic acid having the strongest bacteriocidal effect (KOHLHEB 1978, PRIGGE and HEIER 1982). Another good preservative was formalin used at a level of $0.2-0.4 \%$ together with acid (NØRGAARD PEDERSEN et al. 1981). NORGAARD PEDERSEN et al. (1981), however, found that although almost full preservation of the amino acids was achieved by adding formalin, the lysine content still showed a decrease of $20 \%$. Formaldehyde-treated rapeseed meal was found to have a lower lysine content than untreated meal, and digestibility and protein utilization were also poorer when it was fed to growing pigs (KOWALCZYK and OTWINOWSKA 1983). A study should be made of the changes, occurring in the physical and chemical properties of the protein of LPC when formalin is used as an additive.

Wet preservation of LPC has advantages over dry preservation. The latter method is more expensive and substantial damage of amino acids and carotene can occur during drying, particularly when high temperatures and/ or long drying times are involved. Wet LPC (40\% DM) and low-moisture cereals $(7-8 \%)$ have been used to produce nutritionally balanced pellets with a moisture content of 15-16\% (FOOT 1974). Anaerobic fermentation has been used to coagulate the protein in lucerne juice and to preserve the leaf protein coagula, and this method reduced the oxidative losses of lysine and methionine occurring when juice was heated in the presence of air (STAHMANN 1978).

Wet preservation of leaf protein concentrate can be recommented when the additives used are $1 \%$ formic acid, a mixture of acids or a mixture of formalin and acid. Fermentation losses and protein degradation were reduced to a minimum with this method. The quality of the protein in LPC preserved in wet form may be superior to that in the dried product. Wet preserved LPC deserves to be tried as a protein supplement in cereal-based diets for pigs.

\section{References}

BAKON, J. S. D. 1974. Extraction and use of juice from lucerne and grass. Natl. Inst. Res. Dairying. Mimeogr. p. 16.

BARBER, R. S., BRAUDE, R., MITCHELL, K. G., PATRIDGE, I. G. \& PITTMAN, R. J. 1979. Value of lucerne juice and grass juice as sources of protein for the growing pig. Anim. Feed. Sci. Technol. 4: 233-262.

BARKER, S. B. \& SUMMERSON, W. H., 1941. The colorimetric determination of lactic acid in biological material. J. Biol. Chem. 138: 535-554. 
CHEESMAN, G. C. 1977. The chemical composition of forage juice and its preservation. Occ. Symp. Br. Grassl. Soc. No 9: 39-46.

CONNELL, J. \& FOXELL, P. R. 1976. Green crop fractionation, the products and their utilization by cattle, pigs and poultry. Bienn. Rev. Natn. Inst. Res. Dairy 21: 21-41.

FOOT, A. S. 1974. Lucerne juice for pigs. Pig farming 22(9): 71.

FOXELL, P. R. 1977. The separation and preservation of leaf-protein concentrate for animal feeds. Occ. Symp. Br. Grassl. Soc. No 9: 97-105.

HUIDA, L. 1973. Haihtuvien rasvahappojen kvantitatiivinen määrittäminen pötsinesteestä ja säilörehusta kaasu-nestekromatograafisesti. J. Scient. Agricl Soc. Finl. 45: 485-488.

KOHLHEB, R. 1978. Gewinnung von Nährstoffkonzentraten aus grünen Pflanzen. Diss. Göttingen.

KOWALCZYK, J. \& OTWINOWSKA, A. 1983. Digestion by pigs of diets with formaldehyde-treated rapeseed oilmeal. Z. Tierphysiol. Tierernähr. Futtermittelk. 49: 38-43.

MCDONALD, P. 1981. The biochemistry of silage. Chichter 226 p.

McCULLOUGH, H. 1967. The determination of ammonia in whole blood by a direct colorimetric method. Clin. Chem. Acta 17: 297-304.

MORRIS, T. R. 1977. Leaf-protein concentrate for non-ruminant farm animals. Occ. Symp. Br. Grassl. Soc. No 9: 67-82.

NØRGAARD PEDERSEN, E. J., WITT, N., MORTENSEN, J. \& SØRENSEN, C. 1981. Fractionering af grøn af grøder ved udpresning af saft og konservering af presset af grøde og saft. II Konservering af saft. Tidsskr. Planteavl. 85: 13-30.

NÄSI, M. 1983 a. Extraction of leaf protein from green crops. Chemical composition and nutrive value of products of fractionation. J. Scient. Agric. Soc. Finl. 55: 143-154.

,- 1983 b. Leaf protein production from energy willow leaves. J. Scient. Agric. soc. Finl. 55: 155-162.

PATTERSON, D. C. \& WALKER, N. 1979. The use of effluent from grass silage in the diet of finishig pigs. II Assessment of nutrive value of fresh and stored effluent. Anim. Feed Sci. Technol. 4: 275293.

PIRIE, N. W. 1978. Leaf protein and other aspects of fodder fractionation. 169 p. Camb. Univ. Press. London.

PRIGGE, H. \& HEIER, W. 1982. Konservierung von abgepresstem Pflanzensaft. Z. Wirtschaftseigene Futter 28: 47-52.

STAHMANN, M. A. 1978. Anaerobic fermentation for coagulation of plant juice protein and preservation of the protein and fibrous residues. Proc. $2^{\text {nd }}$ Internat. Green Crop Drying Congress p. 42-49. Saskatchewan.

STEWART, C. S. \& HOUSEMAN, R. A. 1977. The preservation of grass juice. Eur. J. Appl. Microbial 4: 131-136.

Acknowledgements. Thanks are due to Mr. Timo Laitinen for technical assistance.

Ms received September 29. 1983. 


\section{Ruohomehun ja kostean lehtivalkuaistiivisteen säilöntä kotieläin- ten rehuksi}

\section{Matti Näsi}

Helsingin yliopisto, kotieläintieteen laitos, 00710 Helsinki 71

Tutkimuksessa selvitettiin heinä- ja palkokasveista erotetun ruohomehun ja siitä saostamalla saadun lehtivalkuaistiivisteen säilöntää. Säilöntäaineina käytettiin säilörehun valmistuksessa normaalisti käytettäviä muurahaishappoa, happoseoksia (AIV 1 ja AIV 2) sekä formaliini-happoseoksia (Viherliuos ja Viherhappo) $0.25-3,0 \% \mathrm{v} / \mathrm{w}$ annostelutasolla. Säilöntäkokeet tehtiin $0.5-1.0 \mathrm{~kg}$ :n erissä lasipulloihin ja muovirasioihin. Säilöntäaikana (60-120 d) seurattiin mehujen ja tiivisteiden homehtumista ja käymistä. Säilönnän päätyttyä mehut ja tiivisteet analysoitiin sekä selvitettiin säilöntätappioiden suuruus ja tapahtuneet kemialliset muutokset. Mehut säilyivät hyvin käytettäessä $0.5 \% \mathrm{v} / w$ säilöntäainetta, mutta puhdasproteiinin hajoamista tapahtui kaikissa koejäsenissä. Kostea lehtivalkuaistiiviste säilyi hyvin käytettäessä $1 \%$ $\mathrm{v} / \mathrm{w}$ säilöntäainetta. Lehtivalkuaistiivisteet oli saostettu kuumentamalla, joten niissä olevat proteolyyttiset entsyymit olivat tuhoutuneet ja säilönnän aikana puhdasproteiinin hajoaminen oli hyvin vähäistä. 